Bulgarian Academy of Sciences. Space Research and Technology Institute.

Aerospace Research in Bulgaria. 29, 2017, Sofia

\title{
SATELLITE SENSORS USED IN THERMAL REMOTE SENSING
}

\author{
Ivan Yanev \\ ESRI Bulgaria Ltd. \\ e-mail: ivan.yanevmail@gmail.com
}

\begin{abstract}
The presented article makes an overview of the most used contemporary satellite remote sensing missions operating in the thermal range of the electromagnetic spectrum. Discussed are the main environmental applications of satellite missions such as Landsat, ASTER, MODIS, CBERS and $H J-1 B$. Some issues and future perspectives are outlined in conclusion.
\end{abstract}

\section{Introduction}

With the advent of the first satellites equipped with equipment operating in the thermal range in the early 1970s, the Earth's surface temperature has been also studied by remote sensing. Urban climate and environmental studies would be rather difficult, if not impossible, without the ability of satellite sensors to capture images in the thermal range [1]. Today there is a wide variety of sensors that record such data. They range from low spatial resolution (several tens $\mathrm{km}$ to $1 \mathrm{~km}$ ) with acquisition capability every day or even several hours (MODIS, AVHRR) to medium spatial resolution ( $\sim 60 \div 90 \mathrm{~m})$ and only 1-2 times a month Landsat ETM+, ASTER, see Table 1. Depending on the spatial coverage, some sensors are more suitable for mapping of large areas, while others provide monitoring of small regions. Temporal resolution determines for what time period the temperature model can be explored - daily, weekly, monthly, or yearly.

The presence of multiple instruments, recording data in the thermal part of the electromagnetic spectrum, also requires a good knowledge to choose the most appropriate or combination of sensors for the purpose of the particular study. Depending on the purpose of the study, the characteristics of the sensors used spatial resolution, the opportunity to revisit the territory or the temporal resolution, the radiometric resolution that determines the number of brightness levels in the image, the number of spectral bands, as in the thermal range, as well as in the whole electromagnetic spectrum. 
Table 1. Sensors in the thermal rangeof the electromagnetic spectrum [2-4, with changes]

\begin{tabular}{|c|c|c|c|c|c|c|c|}
\hline Sensor & Platform & 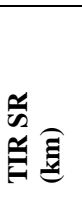 & 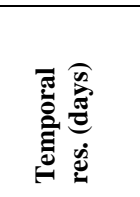 & 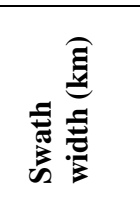 & 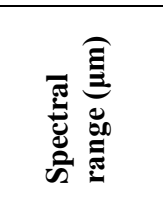 & Agency & $\begin{array}{l}\text { Start } \\
\text { Year }\end{array}$ \\
\hline SR & ITOS-1 & 7.4 & & & & NASA & 1970 \\
\hline VHRR & $\begin{array}{l}\text { NOAA-3, } \\
-5\end{array}$ & 1.0 & & & $\sim 6.00 \div 15.0$ & NOAA & \\
\hline HCMM & HCMR & 0.6 & 16 & 715 & $10.50 \div 12.5$ & NASA & 1978 \\
\hline AVHRR & $\begin{array}{l}\text { NOAA-6, } \\
-7\end{array}$ & 1.1 & & & $10.30 \div 12.5$ & NOAA & \\
\hline ETM+ & Landsat 7 & 0.06 & 16 & 185 & $10.40 \div 12.5$ & $\begin{array}{l}\text { USGS, } \\
\text { NASA }\end{array}$ & 1999 \\
\hline $\mathrm{TM}$ & Landsat 5 & 0.12 & 16 & 185 & $10.40 \div 12.5$ & $\begin{array}{l}\text { USGS, } \\
\text { NASA }\end{array}$ & 1984 \\
\hline TIRS & Landsat 8 & 0.1 & 17 & 186 & $10.90 \div 12.0$ & $\begin{array}{l}\text { USGS, } \\
\text { NASA }\end{array}$ & 2013 \\
\hline ASTER & TERRA & 0.09 & 4-16 & 60 & $8.125 \div 11.6$ & NASA & 1999 \\
\hline IRMSS & $\begin{array}{l}\text { CBERS-1, } \\
-2,-2 b\end{array}$ & 0.16 & 26 & 120 & $10.40 \div 12.5$ & $\begin{array}{l}\text { CRESDA } \\
\text { INPE }\end{array}$ & $\begin{array}{l}1999 / \\
2003, \\
2003, \\
2007 / \\
2010\end{array}$ \\
\hline IRSCAM & $\begin{array}{l}\text { CBERS-3 } \\
\text { and }-4,4 b\end{array}$ & 0.08 & 26 & 120 & $10.40 \div 12.5$ & $\begin{array}{l}\text { CRESDAI } \\
\text { NPE }\end{array}$ & $\begin{array}{l}2012, \\
2014, \\
2016\end{array}$ \\
\hline MERSI & $\begin{array}{l}\text { FY-3A, } \\
F Y-3 B\end{array}$ & 0.25 & 1 & 2800 & 11.25 & $\begin{array}{l}\text { NRSCC, } \\
\text { CAST, } \\
\text { NSM a.o. }\end{array}$ & $\begin{array}{l}2008, \\
2010\end{array}$ \\
\hline InfraredCam & HJ-1B & 0.3 & 31 & 720 & $10.50 \div 12.5$ & $\begin{array}{l}\text { CRESDA } \\
\text { CAST, } \\
\text { NRSCC }\end{array}$ & 2008 \\
\hline NIRST & Aquarius & $\begin{array}{c}0.35 \\
1\end{array}$ & $<1-2$ & $182-1060$ & $10.70 \div 11.7$ & $\begin{array}{l}\text { NASA, } \\
\text { CONAE }\end{array}$ & 2011 \\
\hline BIRD & BIRD & 0.37 & 10 & 190 & $8.50 \div 9.30$ & DLR & $\begin{array}{l}2001 / \\
2004 \\
\end{array}$ \\
\hline TET-1 & TET-1 & $\begin{array}{c}0.35 \\
6\end{array}$ & 10 & 180 & $8.50 \div 9.30$ & DLR & 2012 \\
\hline VIIRS & $\begin{array}{l}\text { Suomi } \\
\text { NPP }\end{array}$ & 1.6 & $<1$ & 3000 & $8.40 \div 12.49$ & $\begin{array}{l}\text { NASA/ } \\
\text { NOAA }\end{array}$ & 2011 \\
\hline CrIS & $\begin{array}{l}\text { Suomi } \\
\text { NPP }\end{array}$ & 14 & $<1$ & 2200 & $9.14 \div 15.38$ & $\begin{array}{l}\text { NASA/ } \\
\text { NOAA }\end{array}$ & 2011 \\
\hline CERES & $\begin{array}{l}\text { Suomi } \\
\text { NPP }\end{array}$ & 20 & $<1$ & 3000 & $8.00 \div 12.00$ & $\begin{array}{l}\text { NASA/ } \\
\text { NOAA }\end{array}$ & 2011 \\
\hline IIR & CALIPSO & 1 & 16 & 64 & $8.65 \div 12.05$ & CNES & 2006 \\
\hline MODIS & $\begin{array}{l}\text { TERRA, } \\
\text { AQUA }\end{array}$ & 1 & 4 per day & 2330 & $10.78 \div 12.27$ & NASA & $\begin{array}{l}1999, \\
2002 \\
\end{array}$ \\
\hline
\end{tabular}




\begin{tabular}{|c|c|c|c|c|c|c|c|}
\hline Sensor & Platform & 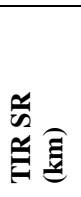 & 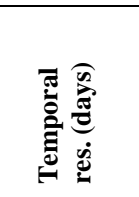 & 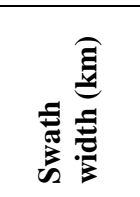 & 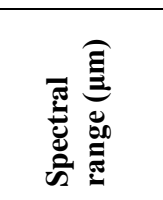 & Agency & $\begin{array}{l}\text { Start } \\
\text { Year }\end{array}$ \\
\hline ATSR-2 & ERS-2 & 1 & 3 & 512 & $\begin{array}{r}10.80 \div \\
12.00\end{array}$ & $\begin{array}{l}\text { ESA, } \\
\text { UKSA, } \\
\text { CSIRO }\end{array}$ & $\begin{array}{l}1995 / \\
2011\end{array}$ \\
\hline AATSR & Envisat & 1 & 35 & 500 & $\begin{array}{r}10.80 \div \\
12.00 \\
\end{array}$ & $\begin{array}{l}\text { ESA, } \\
\text { UKSA }\end{array}$ & $\begin{array}{l}2002 / \\
2012 \\
\end{array}$ \\
\hline AVHRR/1 & $\begin{array}{l}\text { TIROS-N, } \\
\text { NOAA } 6 \text {, } \\
8,10\end{array}$ & 1.1 & $<1$ & 2600 & $10.50 \div 11.50$ & NOAA & $\begin{array}{l}1978 / \\
1986\end{array}$ \\
\hline AVHRR/2 & $\begin{array}{l}\text { NOAA } 9 \text {, } \\
10,11,12 \text {, } \\
13,14\end{array}$ & 1.1 & $<1$ & 3000 & $10.30 \div 11.30$ & NOAA & $\begin{array}{l}1984 / \\
2005\end{array}$ \\
\hline AVHRR/3 & $\begin{array}{l}\text { NOAA } \\
\text { 15-19, } \\
\text { Metop A, } \\
\text { B }\end{array}$ & 1.1 & $<1$ & 3000 & $10.30 \div 12.5$ & $\begin{array}{l}\text { NOAA, } \\
\text { EUMET- } \\
\text { SAT }\end{array}$ & $\begin{array}{l}1998, \\
2000, \\
2002, \\
2005, \\
2006, \\
2012\end{array}$ \\
\hline $\begin{array}{l}\text { MSG- } \\
\text { SEVIRI }\end{array}$ & $\begin{array}{l}\text { Meteosat- } \\
\text { 8/9/19 }\end{array}$ & $1-3$ & $<1$ & Full disk & $9.38 \div 14.40$ & $\begin{array}{l}\text { ESA, } \\
\text { EUMET- } \\
\text { SAT }\end{array}$ & $\begin{array}{l}2002, \\
2005, \\
2012\end{array}$ \\
\hline MVIRI & $\begin{array}{l}\text { Meteosat- } \\
3 / 4 / 5 / 6 / 7\end{array}$ & 3 & $30 \mathrm{~min}$ & Full disk & $10.50 \div 12.5$ & $\begin{array}{l}\text { EUMET- } \\
\text { SAT, ESA }\end{array}$ & $\begin{array}{l}1988, \\
1989, \\
1991, \\
1993, \\
1997\end{array}$ \\
\hline MSU-MR & $\begin{array}{l}\text { Meteor } 3 \\
\text { M, and - } \\
\text { M N1 }\end{array}$ & 1 & 37 & 3000 & $10.50 \div 12.5$ & $\begin{array}{l}\text { ROS- } \\
\text { HYDRO- } \\
\text { MET a.o. }\end{array}$ & $\begin{array}{l}2001 \\
2009\end{array}$ \\
\hline MSU-GS & $\begin{array}{l}\text { Elektro-L } \\
\text { N1 }\end{array}$ & 4 & geost. <1 & Full disk & $9.20 \div 12.05$ & $\begin{array}{l}\text { ROSHY- } \\
\text { DROM-ET } \\
\text { a.o. }\end{array}$ & 2011 \\
\hline IMAGER & $\begin{array}{l}\text { MTSAT- } \\
1,2,3\end{array}$ & 4 & geost. <1 & Full disk & $10.30 \div 12.5$ & JMA & $\begin{array}{l}1999, \\
2006, \\
2013 \\
\end{array}$ \\
\hline MVISR & $\begin{array}{l}\text { FY-1C, } \\
\text { 1D }\end{array}$ & 1.1 & $3-4$ & 3200 & $10.50 \div 12.5$ & $\begin{array}{l}\text { CMA, } \\
\text { NRSCC }\end{array}$ & $\begin{array}{l}1999, \\
2002\end{array}$ \\
\hline IVISSR & $\begin{array}{l}\mathrm{FY}-2 \mathrm{C}, \\
2 \mathrm{D}, 2 \mathrm{E}, \\
2 \mathrm{~F}\end{array}$ & 5 & 1 & Full disk & $10.30 \div 12.5$ & $\begin{array}{l}\text { NRSCC, } \\
\text { CAST, } \\
\text { NSMC }\end{array}$ & $\begin{array}{l}2004, \\
2006, \\
2008, \\
2012\end{array}$ \\
\hline VHRR & $\begin{array}{l}\text { Insat-2A, } \\
E,-3 A\end{array}$ & 8 & $30 \mathrm{~min}$ & Full disk & $10.50 \div 12.5$ & ISRO & $\begin{array}{l}1992, \\
1993, \\
1999, \\
2003\end{array}$ \\
\hline
\end{tabular}




\begin{tabular}{|c|c|c|c|c|c|c|c|}
\hline Sensor & Platform & 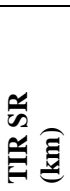 & 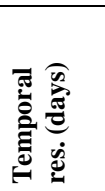 & 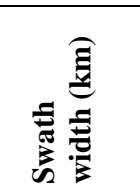 & 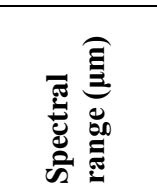 & Agency & $\begin{array}{l}\text { Start } \\
\text { Year }\end{array}$ \\
\hline IASI & $\begin{array}{l}\text { MetOP- } \\
\text { A/B }\end{array}$ & 25 & 29 & 2052 & $8.26 \div 15.50$ & $\begin{array}{l}\text { CNES, } \\
\text { EUMETS } \\
\text { AT }\end{array}$ & $\begin{array}{l}2006, \\
2012\end{array}$ \\
\hline HIRS/3 & $\begin{array}{l}\text { NOAA- } \\
15, \\
-16,-17\end{array}$ & 20.3 & $<1$ & 2240 & 11.11 & NOAA & $\begin{array}{l}1998, \\
2000, \\
2002\end{array}$ \\
\hline HIRS/4 & $\begin{array}{l}\text { NOAA } \\
\text { 18/19, } \\
\text { MetOP } \\
\text { A/B }\end{array}$ & 20.3 & $<1$ & 2240 & $6.70 \div 15.00$ & $\begin{array}{l}\text { NOAA, } \\
\text { EUMETS } \\
\text { AT }\end{array}$ & $\begin{array}{l}2005, \\
2006, \\
2009, \\
2012\end{array}$ \\
\hline ScaRaB & $\begin{array}{l}\text { Meteor-3, } \\
\text { Resurs-01, } \\
\text { Megha } \\
\text { Tropiques }\end{array}$ & 40 & 1 & 2200 & $10.50 \div 12.5$ & CNES & $\begin{array}{l}1994, \\
1998, \\
2011\end{array}$ \\
\hline $\begin{array}{l}\text { GOES } \\
\text { imager }\end{array}$ & GOES & 4 & 3 hours & Full disk & $10.20 \div 12.5$ & & 1974 \\
\hline
\end{tabular}

The most commonly used surface temperature sensors are presented in the following Table 2 .

Table 2. The most commonly used satellite sensors for LST extraction [4]

\begin{tabular}{|l|l|l|l|l|}
\hline Sensor & SR & TR & Satellite & Agency \\
\hline MSG-SEVIRI & $1-3 \mathrm{~km}$ & $<1 \mathrm{~d}$ & Meteosat-8,9, 19 & ESA/EUMETSAT \\
\hline AVHRR & $1.1 \mathrm{~km}$ & $<\mathrm{d}$ & NOAA & NOAA, EUMETSAT \\
\hline MODIS & $1 \mathrm{~km}$ & 4 per day & TERRA, AQUA & NASA \\
\hline AATSR & $1 \mathrm{~km}$ & $35 \mathrm{~d}$ & Envisat & ESA, UKSA \\
\hline InfraredCam & $300 \mathrm{~m}$ & $31 \mathrm{~d}$ & HJ-1B & CRESDA, CAST, NRSCC \\
\hline MERSI & $250 \mathrm{~m}$ & $1 \mathrm{~d}$ & FengYun & NRSCC, CAST, NSM, \\
MVISR & $1.1 \mathrm{~km}$ & $3-4 \mathrm{~d}$ & & CMA \\
IVISSR & $5 \mathrm{~km}$ & $1 \mathrm{~d}$ & & \\
\hline IRMSS & $160 \mathrm{~m}$ & $26 \mathrm{~d}$ & CBERS-2 & CRESDA, INPE \\
\hline TM & $120 \mathrm{~m}$ & $16 \mathrm{~d}$ & Landsat 5 & USGS, NASA \\
\hline ETM+ & $60 \mathrm{~m}$ & $16 \mathrm{~d}$ & Landsat-7 & USGS, NASA \\
\hline ASTER & $90 \mathrm{~m}$ & $16 \mathrm{~d}$ & Terra & NASA \\
\hline
\end{tabular}


According to the Scopus indexed documents, the sensors with the highest spatial resulution are the most commonly used. Therefore, leaders in this regard are sensors aboard Landsat, followed by ASTER and MODIS. Of course, this is highly dependent on the scale of the study. For example, for large-scale studies, the lower spatial resolution is not an obstacle, so the most used sensors in this case are MODIS and NOAA AVHRR. Fig. 1 presents the thermal sensors most commonly used in the articles in Scopus.

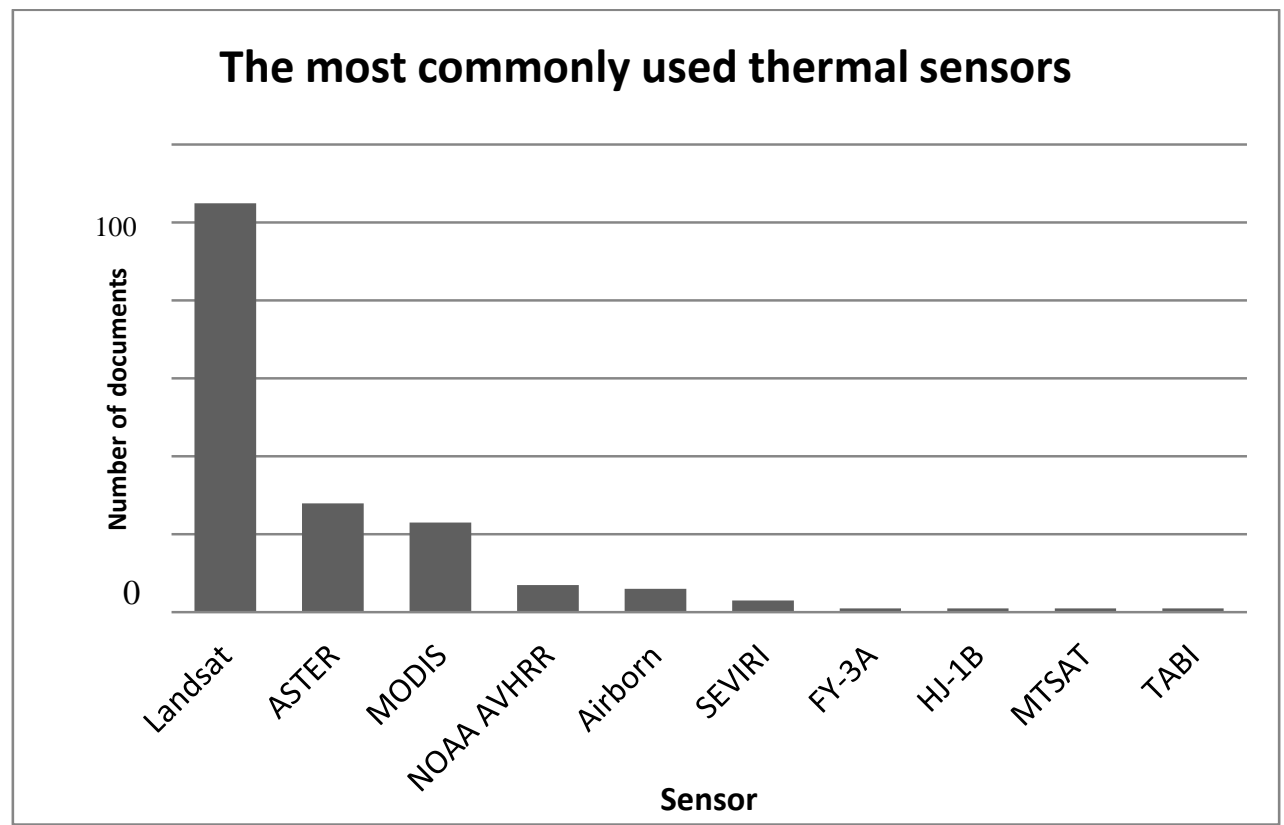

Fig. 1. The most commonly used thermal sensors according to Scopus

Despite the relatively weaker interest in thermal satellite data studies (compared to the visible range of the electromagnetic spectrum, for example), applications in this area are quite wide - agriculture, climatology, hydrology, analysis of urban thermal islands and thermal pits, monitoring of volcanoes, geothermal analysis, forest fires and exposure of burned areas, observation of industrial zones, extraction of soil moisture data etc. In addition, thermal data is used not only for land applications but also on the water surface of the Earth by extracting Sea Surface Temperature (SST). It is quite natural for different applications that there are different sensing requirements for the remote sensors. Since the urban environment is quite heterogeneous, high spatial resolution (SR) sensors are needed for its study. Unfortunately, despite the wide variety of thermal sensors, there are several limiting factors in the choice of images: 1). There is a 
lack of high SR sensors in the thermal range. The highest SR at the moment is 60 $\mathrm{m}$ from Landsat 7 ETM+. This necessitates the use of algorithms for artificially improving the SR; The higher the SR, the lower the temporal resolution and vice versa. This appears to be a limiting factor in exploring the dynamics of temperature on a large scale, particularly in cities; due to the high and densely built-up urban areas, images captured in a central projection are required. Below is a description of some of the most frequently used remote sensing sensors - ETM+, ASTER, CBERS, HJ-1B, and MODIS.

\section{Landsat}

Landsat 7 ETM+ has for many years been, in a scientific jargon, the "work horse" for thermal remote sensing. The Landsat ETM+ sensor has one thermal band in the range $10.4 \div 12.5 \mu \mathrm{m}$ delivering data with $60 \mathrm{~m}$ SR [5]. Each band records data either in low- or high-gain mode, depending on the Sun's angle and the type of land cover specified in the Long Term Acquisition Plan (LTAP) land/land, desert, ice/snow, water, sea ice, and volcano. These types of land cover are pre-mapped. Only band 6 of Landsat 7 is always available in low- and highgain mode, which extends the range of registered temperature values. However, detect illumination may occur if the surface has an extremely high temperature, and vice versa, the surface will not be captured if its temperature is below a certain threshold. The minimum and maximum temperatures in the low-gain mode range from - 34 to $51{ }^{\circ} \mathrm{C}$ and high-gain respectively -134 to $77^{\circ} \mathrm{C}$. These are the temperature values that can be captured within one pixel in Band 6. Band 5 (middle infrared), with a wavelength of $1.55 \div 1.75 \mu \mathrm{m}$, can be used to detect thermal anomalies with temperature values of $200 \div 450{ }^{\circ} \mathrm{C}$, which lead to saturation of Band 6. Even Band 4 (NIR) offers the possibility of exploring extremely high temperatures - 600 $\div 1000{ }^{\circ} \mathrm{C}$. Although low- and high-gain options are new compared to the previous Landsat TM, the thermal band of ETM+ is less suitable for high temperature testing. Its maximum is 51 and $77^{\circ} \mathrm{C}$, while on Band 6 of the TM sensor this value is about $90^{\circ} \mathrm{C}$. As a disadvantage of ETM+, an obsolete 8 bit dynamic range (radiometric resolution) can be seen as a limiting factor for the brightness levels to 256 instead of 4 096, for example if a 12 bit system is used. The main difference between Landsat TM and ETM + is SR - $120 \mathrm{~m}$ (at $60 \mathrm{~m}$ for $\mathrm{ETM}+$ ), lack of double gain as well as absence of panchromatic channel in the visible range and weaker radiometric sensitivity. At special order it is possible to capture at night (only in the thermal channel). However, the number of the night data is limited, as more energy (downstream orbit) is consumed to capture. The capture of one scene leads to skipping seven day scenes when the orbit is ascending. The data from the ETM+ have been available since 1999. However, in May 2003 a failure occurred in one of the scanning mirrors. According to official data, 78 \% of data are unaffected. Since February 2013, the latest Landsat Data 
Continuity Mission (LDCM) sensor has been in orbit, which also has a thermal sensor, but unfortunately its SR is only $100 \mathrm{~m}$. The LDCM specifications are comparable to those of the previous sensors - SR, swath width, radiometric and geometric accuracy, range of bands. Both the Operational Land Imager (OLI), VIS, NIR and SWIR and TIRS (thermal infrared sensor), are pushbroom sensors, while the previous Landsat sensors are whiskbroom type. The technological improvements of the new heat sensor include pushbroom mode, two spectral bands, TIRS optics are cooled to reduce side noise, better signal-to-noise ratio (SNR), and 12-bit data allow for more accurate temperature measurements with a range of -330 to $870{ }^{\circ} \mathrm{C}$ - a slightly higher range than previous sensors. An important advantage of TIRS is the presence of two spectral bands with a central wavelength of 10.9 and $12 \mu \mathrm{m}$. This allows the thermal influence of the atmosphere to be compensated for transforming the sensors recorded at the surface temperature. In order to do this with the ETM+ thermal band, additional atmospheric status data should be used.

\section{ASTER}

Since December 1999, ASTER has been orbiting in a polar, solarsynchronous orbit (30 minutes behind Landsat 7), and data began to receive at the end of February 2000 with a 16-day revisiting period [6]. The registered images cover an area of $60 \mathrm{~km} \times 60 \mathrm{~km}$ and are captured around 10:30 AM local time. Unlike Landsat 7, which records data permanently and thus provides coverage almost all over the world (excluding poles), ASTER scans the Earth's surface only at the request of users and therefore does not guarantee coverage of a given territory. Night images with 5 thermal bands, taken around 10:30 local time, can also be tasked. A great advantage of the thermal night data is that at that time the Sun's influence on the heat signal is almost completely eliminated. The impact of unequal heating due to tilt and exposure is minimized. The great advantage and unique feature of ASTER is the presence of 5 spectral bands in the thermal range between 8.125 and $11.65 \mu \mathrm{m}$, the $90 \mathrm{~m} \mathrm{SR}$ and the 12 bits dynamic range. For MODIS, there are two channels in the thermal range, and the $1 \mathrm{~km} \mathrm{SR}$. ASTER therefore provides a spectrum of surface emissivity based on 5 measurements, as the transmitting power varies with the wavelength.

\section{MODIS}

The MODIS sensor records data in 36 spectral channels in the range between 0.62 and $14.385 \mu \mathrm{m}$ [7, 8]. The spatial resolution is $250 \mathrm{~m}$ for VIS bands 1 and 2, $500 \mathrm{~m}$ for bands 3-7 (VIS - NIR) and $1000 \mathrm{~m}$ for other channels from 8 to 36 (visible, near infrared (NIR), medium IR (MIR) and thermal (TIR) infrared, at the maximum shooting angle of $55^{\circ}$ pixels at the margins of the image can be between 2 and $5 \mathrm{~km}$, however, the wide range of the sensor ensures a high shooting 
frequency so that the data of MODIS are available daily for the vast majority of the earth's surface. MODIS is on board of two satellite platforms - Terra (1999) and Aqua (2002), which allows most areas to be captured 4-5 times per day, including nighttime imaging, allowing for the accumulation of long time series without cloud coverage, for thermal exploration using bands 20-23 with a spectral range of $3.66 \div 4.08 \mu \mathrm{m})$ and most of all bands 31 and $32(10.78 \div 12.27 \mu \mathrm{m})$.

\section{Chine-Brazil Earth Resource Satellite (CBERS)}

CBERS-1 has been operating from 1999 to 2003 when the CBERS-2 is being delivered in orbit and it is delivering data to this day [9]. Infrared MutiSpectral Scanner (IRMSS) is one of the three satellite instruments that has a thermal band $(10.4 \div 12.5 \mu \mathrm{m})$ with $156 \mathrm{~m}$ SR [10]. CBERS-2b has been running for 3 years starting in 2007. The CBERS-3, originally planned for 2010, then autumn 2012, is still launched in December 2013. However, a problem with the carrier rocket has led to the loss of the satellite, which carries an improved infrared scanner that delivers thermal data $(10.4 \div 12.5 \mu \mathrm{m})$ with $80 \mathrm{~m} \mathrm{SR}$ and a swath width of $120 \mathrm{~km}$. Depth of acquisition is $8 \mathrm{~m}$. The panchromatic band has a SR of $5 \mathrm{~m}$ and the multispectral $10 \mathrm{~m}$ and a swath width of $60 \mathrm{~km}$. CBERS-4 is on a sunsynchronous orbit from the end of 2014, although planned for 2015, replacing the failed mission of CBERS-3. The CBERS-4b are in the production phase and are not yet in orbit, although it is planned for 2016.

\section{HJ-1B}

HJ-1B is the second of the three HJ satellites (HuanJing, "environment" in Chinese) [10]. HJ-1A and HJ-1B were removed in September 2006, and in November $2012 \mathrm{HJ}-1 \mathrm{C}$. The three satellites are mainly used for natural disasters and environmental monitoring. They provide multispectral and radar images. The HJ-1A, which has 2 thermal bands with $1.1 \mathrm{~km} \mathrm{SR}$, is no longer operating. The HJ$1 \mathrm{~B}$ features an infrared camera that outputs data in the thermal range between $10.5 \div 12.5 \mu \mathrm{m}$ at $300 \mathrm{~m}$ SR and $720 \mathrm{~km}$ swath. A MIR channel between $3.5 \div 3.9$ $\mu \mathrm{m}$ collects data with $150 \mathrm{~m} \mathrm{SR}$ and allows detection of extreme temperature anomalies. Thermal data from HJ-1B is mainly used for more generalized LST studies.

\section{Issues and Perspectives}

A major issue of thermal satellite data is the low SR. The SR of the thermal images by the currently operating satellites is not high enough, especially when exploring an urban environment where the Earth's surface is extremely heterogeneous. The lack of proper SR leads to the need to use different algorithms for its "artificial" improvement (downscaling) [11-14]. 
Temporal resolution (TR) is another problem, especially when it comes to exploring dynamic processes. It is, for example, difficult to investigate 24-hour LST changes in cities. High SR heat tools perform no more than 2 observations per month. The basic pattern in thermal imaging is the inverse proportionality between SR and TR - the higher the SR, the lower the TR and vice versa.

Another factor to be taken into account is the urban scattering surface and the instantaneous field of view (IFOV) of the sensor. To extract LST in an urban environment, a tool is needed that "sees" the Earth's surface in a central projection. This is another limiting factor in selecting images for a particular territory.

Speaking of SR and TR of thermal data, the user community needs a high-speed satellite and a roughly daily revisit [15]. There are currently several projects that are trying to meet the user's expectations. One of them, MISTIGRI (MicroSatellite for Thermal Infrared Ground Surface Imaging), is a joint project between the French Space Agency (CNES) and the University of Valencia, Spain. Currently, the project is completed in phase A. TIREX (Thermal Infrared Explorer) is a proposal submitted in 2010 to an announcement of opportunity by the European Space Agency (EEA) on Earth Explorer Opportunity Missions. In the end, the proposal was rejected for phase A. Both missions should have about $50 \mathrm{~m}$ SR and a re-visiting time of 1 or 2 days. The HyspIRI (Hyperspectral Infrared Imager) project developed by NASA is expected to capture thermal data with $60 \mathrm{~m}$ SR and 5 days of re-visit. The mission is currently under study.

In conclusion, further research is needed in the other areas of LST applications. Thermal IRs has already a number of applications, but research focuses on a narrower range of topics. These data provide a good opportunity to combine thermal analysis of buildings, energy losses from buildings, calculation of cooling/heating degree day indices, with the capabilities of the latest 3D modeling products. Another niche for extensive studies is the dynamic processes in urban micro-climate and, in particular, the dynamics of the Earth's surface temperature (LST).

\section{References}

1. Weng, Q. Thermal infrared remote sensing for urban climate and environmental studies: Methods, applications, and trends, ISPRS Journal of Photogrammetry and Remote Sensing, 2009, 64, 4, 335-344. DOI: 10.1016/j.isprsjprs.2009.03.007

2. Voogt, J.A. Thermal remote sensing of urban surface, 1995, The University of British Columbia.

3. Tomlinson, C. J. et al. Remote sensing land surface temperature for Meteorology and climatology: A review, Meteorological Applications, 2011, 18, 3, 296-306.

4. Kuenzer, C. et al. Spaceborne thermal infrared observation - an overview of most frequently used sensors for applied research, in: Kuenzer, C. and S., Dech, (eds) Thermal Infrared Remote Sensing SE-7. Springer Netherlands (Remote Sensing and Digital Image Processing), 131-148. DOI: 10.1007/978-94-007-6639-6_7. 
5. Landsat Missions, https://landsat.usgs.gov/using-usgs-landsat-8-product (last day accessed November 26, 2017)

6. ASTER, https://asterweb.jpl.nasa.gov/ (last day accessed November 26, 2017)

7. MODIS, http://modis.gsfc.nasa.gov/about/design.php (last day accessed November 26, 2017)

8. MODIS Land Team, http://landval.gsfc.nasa.gov/ProductStatus.php?ProductID=MOD11 (accessed Nov. 26, 2017)

9. CBERS, http://www.cbers.inpe.br/ingles (last day accessed November 26, 2017)

10. eoPortal Directory, https://directory.eoportal.org/web/eoportal/satellitemissions/ (last accessed November 26, 2017)

11. Stathopoulou, M. and C. Cartalis, Downscaling AVHRR land surface temperatures for improved surface urban heat island intensity estimation, Remote Sensing of Environment, 2009, 113, 12, 2592-05.

12. Zhiwei, Y., G. Huili, and Z. Wenji, Subpixel urban area thermal pattern analysis using ASTER and SPOT-5, in: 2009 Joint Urban Remote Sensing Event. College of Resource Environment and Tourism, Capital Normal University, Beijing, China (2009 Joint Urban Remote Sensing Event).

13. Cao, G. et al. Analysis on the spatial distribution of urban heat island with downscaled FY-3A VIRR land surface temperature', in Proceedings of the $2^{\text {nd }}$ International Workshop on Earth Observation and Remote Sensing Applications, EORSA 2012. LREVCS, China Meteorological Administration, Beijing, China (2nd International Workshop on Earth Observation and Remote Sensing Applications, EORSA 2012), 2012, 36-40.

14. Zakšek, K. and K. Oštir, Downscaling land surface temperature for urban heat island diurnal cycle analysis, Remote Sensing of Environment. 2012, 117, 114-124.

15. Sobrino, J. et al. Review of High Resolution Thermal Infrared Applications and Requirements: The Fuegosat Synthesis Study, in: Kuenzer, C. and S. Dech, (eds) Thermal Infrared Remote Sensing SE-10. Springer Netherlands (Remote Sensing and Digital Image Processing), 2013, 197-214.

DOI: 10.1007/978-94-007-6639-6_10

\section{СПЪТНИКОВИ СЕНЗОРИ, ИЗПОЛЗВАНИ ЗА ТОПЛИННИ ДИСТАНЦИОННИ ИЗСЛЕДВАНИЯ}

\section{Ив. Янев}

\section{Резюме}

Настоящата статия прави преглед на най-използваните съвременни спътникови мисии, работещи в топлинния диапазон на електромагнитния спектьр. Обсъдени са основните приложения в изследванията на околната среда с помощта на данни от спътникови мисии като Landsat, ASTER, MODIS, CBERS и HJ-1B. В заключение се очертават някои проблеми и бъдещи перспективи пред спътниковите топлинни дистанционни изследвания. 